\title{
Preparation of highly dispersed iron species over ZSM-5 with enhanced metal-support interaction through freeze-drying impregnation
}

\author{
Lisong Fan, Dangguo Cheng *, Fengqiu Chen, Xiaoli Zhan \\ Zhejiang Provincial Key Laboratory of Advanced Chemical Engineering Manufacture Technology, College of Chemical and Biological Engineering, \\ Zhejiang University, Hangzhou 310027, Zhejiang, China
}

\section{A R T I C L E I N F O}

\section{Article history:}

Received 4 October 2018

Accepted 9 November 2018

Published 5 July 2019

\section{Keywords:}

Iron

ZSM-5 zeolite

Freeze drying

Impregnation

Metal-support interaction

Metal size

\begin{abstract}
A B S T R A C T
Supported metal catalysts play a vital role in the chemical industry, and the metal-support interaction is an important property of the catalyst. However, in the traditional impregnation method, it is difficult to obtain sufficient metal-support interactions owing to the mobility of the metal precursor during evaporation drying. Here, freeze drying is applied during impregnation instead of evaporation drying for enhancing the metal-support interactions. ${ }^{57} \mathrm{FeZSM}-5$ was chosen as a representative catalyst. A quantitative analysis was conducted based on Mössbauer spectroscopy. Compared with traditional evaporation-drying catalyst, freeze-drying catalyst has stronger metal-support interactions. In addition, more iron species are confined in the channel and smaller metal sizes and less diversity are obtained. The compositional change is also proved because of the superior performance of the freeze-drying catalyst during $\mathrm{N}_{2} \mathrm{O}$ decomposition. This method can be extended to other supported metal catalysts prepared through an impregnation method, which can be used to tune the metal-support interactions and metal sizes.
\end{abstract}

(C) 2019, Dalian Institute of Chemical Physics, Chinese Academy of Sciences. Published by Elsevier B.V. All rights reserved.

\section{Introduction}

Supported metal catalysts are the most widely used type of heterogeneous catalysts and play an important role in the chemical industry [1]. The performance of a supported metal catalyst depends on the properties of the metal, support, and pretreatment [2]. In addition, some studies have found that the interaction between the metal and support can also influence the performance through the carrier effect, which can be used to improve the stability, enhance the activity, and study the underlying mechanism [3-8].

The impregnation method is a simple way to prepare the supported metal catalyst. With this type of method, the support is immersed in a solution of metal precursor, and capillary forces in the pores enable the solvent to be distributed throughout the full support. The resulting catalyst is then set aside for several hours to ensure the equilibrium of the precursor distribution. After drying and calcination, the catalyst is created $[9,10]$. However, during conventional evaporation drying, the solvent will move within the absorbed layer, disturbing the distribution of the metal precursor. Moreover, in a porous support, the capillary pressure will transport the solvent to the external surface. Consequently, a large amount of metal dissolved in a solution will be transported to the external surface,

\footnotetext{
* Corresponding author. Tel: +86-571-87953382; Fax: +86-571-87951227; E-mail: dgcheng@zju.edu.cn

This work was supported by the National Key R\&D Program of China (2016YFA0202900), the National Natural Science Foundation of China (21622606), Zhejiang Provincial Natural Science Foundation of China (LR18B060001), and the Fundamental Research Funds for the Central Universities.

DOI: 10.1016/S1872-2067(18)63198-5 | http://www.sciencedirect.com/science/journal/18722067 | Chin. J. Catal., Vol. 40, No. 7, July 2019
} 
forming significant aggregations [11]. Therefore, it is difficult to obtain sufficient metal dispersion and metal-support interaction over the catalyst. Some researchers have added some viscous materials into the impregnating solution to suppress the liquid movement, providing a more uniform distribution [12]. Vergunst et al. applied microwave drying in preparing a nickel-based monolithic catalyst to avoid metal accumulation [13]. However, research on a general method to increase the metal-support interaction in an impregnation method remains insufficient.

In our study, we used freeze drying instead of traditional evaporation drying to solve the above problem. Freeze drying is used to remove the solvent from a frozen sample through sublimation under vacuum conditions. During sublimation, the mobility of the precursor is greatly restricted $[14,15]$. In the field of chemistry, freeze drying is typically used to synthesize nanometal powders [16]. Nevertheless, this method is rarely applied in impregnation to enhance the metal-support interaction of a catalyst. Herein, Fe and ZSM-5 were selected as the representative metal and support, respectively. FeZSM-F (1.0 wt $\%{ }^{57} \mathrm{Fe}$ ) was prepared through freeze-drying impregnation and compared with the evaporation-drying impregnation cata-

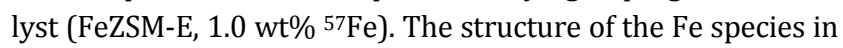
the prepared catalysts and their performance during $\mathrm{N}_{2} \mathrm{O}$ decomposition are discussed. In addition, the formation mechanisms are proposed.

\section{Experimental}

\subsection{Catalyst preparation}

FeZSM-5 catalysts were prepared through impregnation. A certain amount of HZSM- 5 was added into the ${ }^{57} \mathrm{Fe}\left(\mathrm{NO}_{3}\right)_{3}$ solution and stirred for $2 \mathrm{~h}$. In addition, ${ }^{57} \mathrm{Fe}\left(\mathrm{NO}_{3}\right)_{3}$ was created by dissolving ${ }^{57} \mathrm{Fe}$ metal powder with a dilute $\mathrm{HNO}_{3}$ solution at 90 ${ }^{\circ} \mathrm{C}$. After filtering, the well-mixed samples were separated into two parts. One part was dried in oven at $120^{\circ} \mathrm{C}$ for $10 \mathrm{~h}$, whereas the other was immediately frozen using liquid nitrogen and put into a vacuum freeze dryer at $-10^{\circ} \mathrm{C}$ and $1 \mathrm{~Pa}$ for $10 \mathrm{~h}$. The samples were then heated at $550^{\circ} \mathrm{C}$ in air for $8 \mathrm{~h}$. Finally, the samples were calcined in helium flow at $900{ }^{\circ} \mathrm{C}$ for $1 \mathrm{~h}$. The obtained samples were labeled FeZSM-E and FeZSM-F, where $\mathrm{E}$ and $\mathrm{F}$ indicate evaporation drying and freeze drying, respectively.

\subsection{Catalyst characterization}

The magnetic properties were determined at room temperature using a superconducting quantum interference device magnetometer (SQUID, MPMS-XL-5, Quantum Design Company of USA). In FeZSM-5 catalysts, ZSM-5 is a major component with diamagnetism, which exerts a significant influence over the measurement of iron magnetization. Thus, the spectra of ZSM-5 are subtracted from the catalysts to obtain the real spectra of the iron species. The $\mathrm{H}_{2}$ temperature-programmed reduction ( $\mathrm{H}_{2}$-TPR) experiment was conducted using Micromeritics ASAP 2920 to analyze the reducibility of the cata- lysts. Prior to the reduction, the catalyst (50 mg) was treated in flowing $\operatorname{Ar}(50 \mathrm{~mL} / \mathrm{min})$ at $500{ }^{\circ} \mathrm{C}$ for $1 \mathrm{~h}$ and cooled to $50{ }^{\circ} \mathrm{C}$. In addition, $10 \% \mathrm{H}_{2}-\mathrm{Ar}$ was passed through the sample. TCD signals were recorded from 50 to $900{ }^{\circ} \mathrm{C}$ at $10{ }^{\circ} \mathrm{C} / \mathrm{min}$. The ${ }^{57} \mathrm{Fe}$ Mössbauer spectra were determined using a Wissel spectrometer within a velocity range of -11.2 to $+11.2 \mathrm{~mm} / \mathrm{s}$ at room temperature using a ${ }^{57} \mathrm{Co}(\mathrm{Pd})$ source. The isomer shift was given with respect to $\alpha$-Fe at room temperature. The solid-state ${ }^{27} \mathrm{Al}$ NMR experiments were conducted on a Varian InfinityPlus 300 at room temperature with a magnetic field of 7.1 T. In addition, the resonance frequency was $78.13 \mathrm{MHz}$, and the spinning rate of the sample was $8.0 \mathrm{kHz}$. The spectra were referenced to $1 \mathrm{~mol} / \mathrm{L} \mathrm{Al}\left(\mathrm{NO}_{3}\right)_{3}$ at $0 \mathrm{ppm}$.

\section{3. $\mathrm{N}_{2} \mathrm{O}$ decomposition test}

0.1 g catalyst (20-40 mesh size) was loaded into a tubular quartz fixed-bed reactor (I.D. $=8 \mathrm{~mm}$ ) at atmospheric pressure. In addition, $1.0 \% \mathrm{~N}_{2} \mathrm{O}$ with a He balance $(150 \mathrm{~mL} / \mathrm{min})$ was introduced into the reactor. The reactants and products were analyzed using Porapak Q and molecular sieve 5A columns.

\section{Results and discussion}

The magnetic property of the catalysts was investigated using SQUID. As shown in Fig. 1, two catalysts show different shapes, indicating that they have a different Fe magnetic species composition. Hysteresis cycles with a positive slope are observed in both catalysts, indicating at least a mixed property of ferromagnetism and paramagnetism. In iron-supported ZSM catalysts, $\gamma-\mathrm{Fe}_{2} \mathrm{O}_{3}, \alpha-\mathrm{Fe}_{2} \mathrm{O}_{3}$, and $\mathrm{Fe}^{2+}$ bonded with the framework may appear as a ferromagnetic phase [17]. However, $\gamma-\mathrm{Fe}_{2} \mathrm{O}_{3}$ will be transformed into $\alpha-\mathrm{Fe}_{2} \mathrm{O}_{3}$ at above $400{ }^{\circ} \mathrm{C}$ [18]. Because the calcination temperature is $900{ }^{\circ} \mathrm{C}$ during preparation, $\gamma-\mathrm{Fe}_{2} \mathrm{O}_{3}$ should not exist in the catalysts. In addition, the paramagnetic behavior may be ascribed to $\mathrm{Fe}^{3+}$ bonded with the framework [17].

The reducibility of the catalysts was investigated through $\mathrm{H}_{2}$-TPR experiment (Fig. 2). The peaks at $350-600{ }^{\circ} \mathrm{C}$ can be

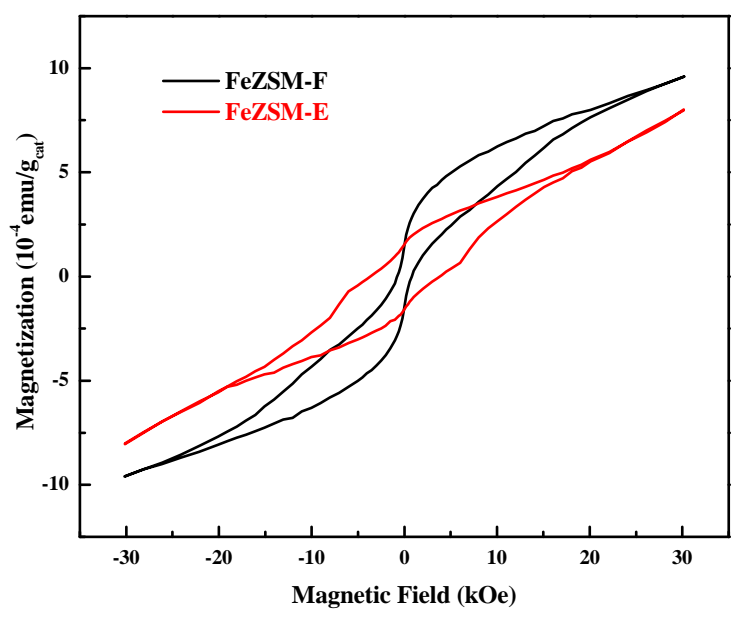

Fig. 1. Magnetization of FeZSM-5 catalysts as a function of the magnetic field. 


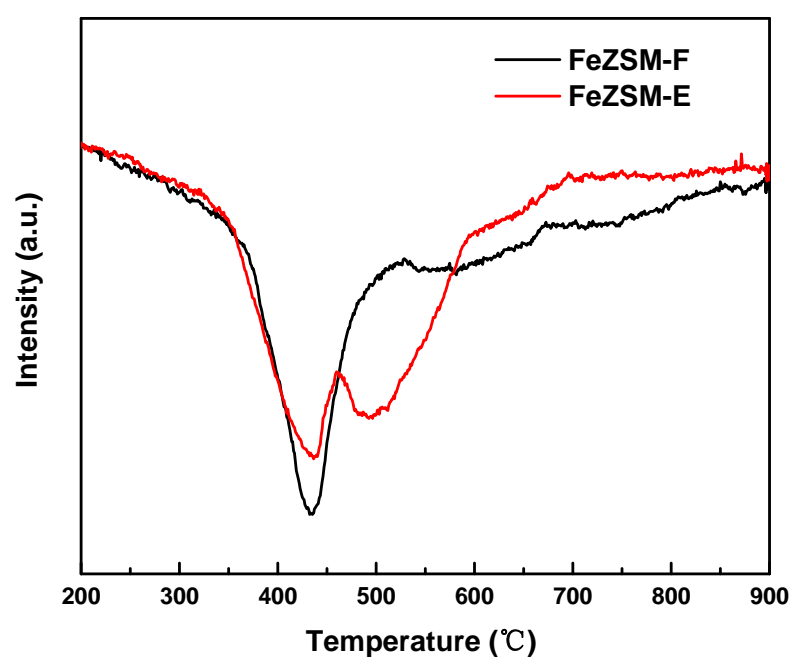

Fig. 2. $\mathrm{H}_{2}$-TPR profiles of FeZSM-5 catalysts.

classified as the reduction of $\mathrm{Fe}^{3+}$ to $\mathrm{Fe}^{2+}$. The $\mathrm{Fe}^{3+}$ species may include isolated $\mathrm{Fe}^{3+}, \mathrm{Fe}_{x} \mathrm{O}_{y}$ clusters, or $\alpha-\mathrm{Fe}_{2} \mathrm{O}_{3}$ nanoparticles [19-21]. Within this range, there are two peaks for FeZSM-E, indicating the diversity of $\mathrm{Fe}^{3+}$ species in FeZSM-E, whereas FeZSM-F only has a single peak. In addition, FeZSM-E has a larger amount of $\mathrm{Fe}^{3+}$ species than FeZSM-F. The peaks at a higher temperature $\left(600-800{ }^{\circ} \mathrm{C}\right)$ represent reduction of $\mathrm{Fe}^{2+}$ to $\mathrm{Fe}^{0}$ [19-21]. According to the integral results, the consumption of $\mathrm{H}_{2}$ is higher for FeZSM-F (0.26 versus $0.24 \mathrm{mmol} / \mathrm{g}$ ). Considering that both catalysts have the same iron content and fewer $\mathrm{Fe}^{3+}$ are reduced to $\mathrm{Fe}^{2+}$ in FeZSM-F, FeZSM-F must possess a greater amount of $\mathrm{Fe}^{2+}$ species.

${ }^{57} \mathrm{Fe}$ Mössbauer spectroscopy is a powerful tool for analyzing the Fe species [22]. In the Mössbauer spectra (Fig. 3), the valence state and coordination of the Fe species are reflected through the isomer shift (IS) and quadrupole splitting (QS), respectively. Table 1 shows the parameters obtained through a spectral devolution. According to the literature [23-25], 0.1-0.6 $\mathrm{mm} / \mathrm{s}$ is assigned to $\mathrm{Fe}^{3+}$, whereas $0.7-1.4 \mathrm{~mm} / \mathrm{s}$ is ascribed to $\mathrm{Fe}^{2+}$. For $\mathrm{Fe}^{3+}$, the IS of lower than $0.3 \mathrm{~mm} / \mathrm{s}$ is within the $\mathrm{T}_{d}$

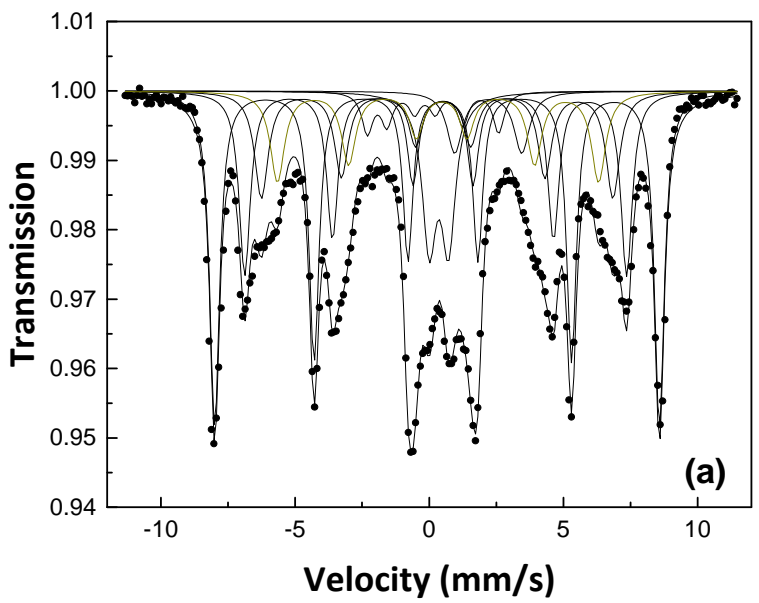

Table 1

Mössbauer parameters, percentages, and Fe species of FeZSM-5 catalysts.

\begin{tabular}{|c|c|c|c|c|c|c|}
\hline Catalyst & Component & $\begin{array}{c}\mathrm{IS} \\
(\mathrm{mm} / \mathrm{s}) \\
\end{array}$ & $\begin{array}{c}\mathrm{QS} \\
(\mathrm{mm} / \mathrm{s}) \\
\end{array}$ & $\begin{array}{l}B_{\mathrm{hf}} \\
(\mathrm{T}) \\
\end{array}$ & $\begin{array}{l}\text { Percent- } \\
\text { age (\%) }\end{array}$ & Fe species \\
\hline \multirow[t]{7}{*}{ FeZSM-E } & Doublet(A) & 0.74 & 1.85 & - & 1.7 & $\mathrm{Fe}^{2+}, \mathrm{O}_{\mathrm{h}}$ \\
\hline & Doublet(B) & 0.79 & 0.42 & - & 7.2 & $\begin{array}{l}\mathrm{Fe}^{2+} \text { in planer } \\
\text { coordination }\end{array}$ \\
\hline & Doublet(I) & 0.11 & 1.23 & - & 3.0 & $\mathrm{Fe}^{3+}-\mathrm{Al}-\mathrm{Si}, \mathrm{T}_{\mathrm{d}}$ \\
\hline & Doublet(II) & 0.36 & 0.87 & - & 12.2 & $\begin{array}{l}\text { Small } \mathrm{Fe}_{x} \mathrm{O}_{y} \text { na- } \\
\text { noparticles, } \mathrm{O}_{\mathrm{h}}\end{array}$ \\
\hline & Sextet(I) & 0.38 & - & 51.2 & 36.1 & $\begin{array}{l}\text { Large } \alpha-\mathrm{Fe}_{2} \mathrm{O}_{3} \\
\text { particles }\end{array}$ \\
\hline & Sextet(II) & 0.39 & - & 43.3 & 21.1 & $\begin{array}{l}\text { Large } \alpha-\mathrm{Fe}_{2} \mathrm{O}_{3} \\
\quad \text { particles }\end{array}$ \\
\hline & Sextet(III) & 0.40 & - & 39.5 & 18.7 & $\begin{array}{l}\text { Large } \alpha-\mathrm{Fe}_{2} \mathrm{O}_{3} \\
\text { particles }\end{array}$ \\
\hline \multirow[t]{4}{*}{ FeZSM-F } & Doublet(A) & 1.04 & 1.22 & - & 29.6 & $\mathrm{Fe}^{2+}, \mathrm{O}_{\mathrm{h}}$ \\
\hline & Doublet(I) & 0.28 & 1.24 & - & 10.4 & $\mathrm{Fe}^{3+}-\mathrm{Al}-\mathrm{Si}, \mathrm{T}_{\mathrm{d}}$ \\
\hline & Doublet(II) & 0.34 & 0.66 & - & 27.4 & $\begin{array}{l}\text { Small } \mathrm{Fe}_{x} \mathrm{O}_{y} \text { na- } \\
\text { noparticles, } \mathrm{O}_{\mathrm{h}}\end{array}$ \\
\hline & Sextet(I) & 0.39 & - & 49.8 & 32.6 & $\begin{array}{l}\text { Large } \alpha-\mathrm{Fe}_{2} \mathrm{O}_{3} \\
\text { particles }\end{array}$ \\
\hline
\end{tabular}

coordination, whereas the IS higher than $0.3 \mathrm{~mm} / \mathrm{s}$ is in the $\mathrm{O}_{\mathrm{h}}$ coordination. Doublet(I) $(0.1 \mathrm{~mm} / \mathrm{s} \leq$ IS $\leq 0.3 \mathrm{~mm} / \mathrm{s}, 0.87$ $\mathrm{mm} / \mathrm{s} \leq \mathrm{QS} \leq 1.24 \mathrm{~mm} / \mathrm{s}$ ) is assigned to $\mathrm{Fe}^{3+}-\mathrm{Al}-\mathrm{Si}$ of the $\mathrm{T}_{\mathrm{d}}$ coordination in the extraframework $[19,26,27]$. Doublet(II) $(0.30$ $\mathrm{mm} / \mathrm{s} \leq$ IS $\leq 0.37 \mathrm{~mm} / \mathrm{s}, 0.65 \mathrm{~mm} / \mathrm{s} \leq \mathrm{QS} \leq 1.06 \mathrm{~mm} / \mathrm{s}$ ) is attributed to small $\mathrm{Fe}_{x} \mathrm{O}_{y}$ nanoparticles in the $\mathrm{O}_{\mathrm{h}}$ coordination with superparamagnetism [23]. Some researchers have suggested that small $\mathrm{Fe}_{x} \mathrm{O}_{y}$ nanoparticles were formed inside the channel [28-30]. Sextet(I), Sextet(II), and Sextet(III) (0.36 $\mathrm{mm} / \mathrm{s} \leq \mathrm{IS} \leq 0.50 \mathrm{~mm} / \mathrm{s}, 39.2 \mathrm{~T} \leq \mathrm{Bhf} \leq 51.4 \mathrm{~T}$ ) belong to large bulk magnetic iron oxide outside ZSM-5, which is larger than 10 $\mathrm{nm}$ [31]. To further confirm the state, we measured the spectra of $30 \mathrm{~nm} \alpha-\mathrm{Fe}_{2} \mathrm{O}_{3}$ (Fig. S1, Table S1) and found a similar IS value but with a different $B_{\mathrm{hf}}$ (hyperfine magnetic field). Thus, we ascribe Sextet(I), Sextet(II), and Sextet(III) to large $\alpha-\mathrm{Fe}_{2} \mathrm{O}_{3}$ particles $(>10 \mathrm{~nm}$ ) with different sizes outside ZSM-5, which is also in line with a former magnetic characterization. For $\mathrm{Fe}^{2+}$, a higher QS is ascribed to higher coordination numbers. Here, Doublet(A) (QS $>1 \mathrm{~mm} / \mathrm{s}$ ) is assigned to $\mathrm{Fe}^{2+}$ in the $\mathrm{O}_{\mathrm{h}}$ coordi-

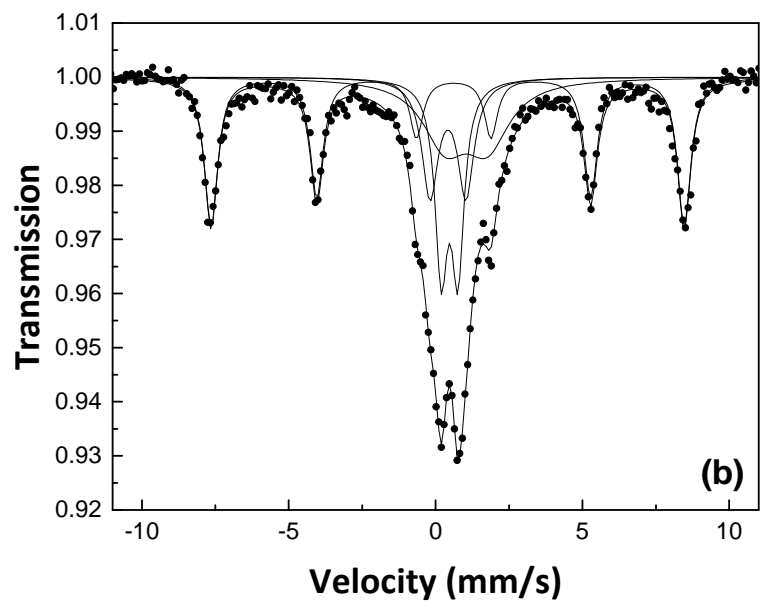

Fig. 3. ${ }^{57} \mathrm{Fe}$ Mössbauer spectra at room temperature over catalysts (a) FeZSM-E and (b) FeZSM-F. 
nation, and Doublet(B) is assigned to mononuclear $\mathrm{Fe}^{2+}$ in the planer coordination $[29,31,32]$.

Table 1 lists the quantitative results. For $\mathrm{Fe}^{3+}-\mathrm{Al}-\mathrm{Si}$, FeZSM-F has a larger amount (10.4\% versus 3.0\%). For Fe ${ }^{2+}$, FeZSM-E contains two types, namely, $\mathrm{Fe}^{2+}$ of the $\mathrm{O}_{\mathrm{h}}$ coordination $(1.7 \%)$ and planer coordination (7.2\%), whereas FeZSM-F only contains $\mathrm{Fe}^{2+}$ in the $\mathrm{O}_{\mathrm{h}}$ coordination (29.6\%), which is much higher than the total $\mathrm{Fe}^{2+}$ amount (8.9\%) in FeZSM-E. Because the formation of $\mathrm{Fe}^{2+}$ is connected with $\mathrm{Al}$ (as illustrated later), and the ${ }^{27} \mathrm{Al}$ MAS NMR spectra (Fig. S2) show that aluminum in ZSM-5 remains predominately in the framework (50 ppm), $\mathrm{Fe}^{3+}-\mathrm{Al}-\mathrm{Si}$ and two $\mathrm{Fe}^{2+}$ types are formed through interactions between the iron and support. It is clear that FeZSM-F has more of these species (40.0\% versus $11.9 \%$ ). Thus, freeze drying contributes more to the enhanced metal-support interactions.

For small $\mathrm{Fe}_{x} \mathrm{O}_{y}$ nanoparticles of the $\mathrm{O}_{\mathrm{h}}$ coordination in the channel, FeZSM-F contains more than twice the amount of FeZSM-E (27.4\% versus $12.2 \%)$. For large $\alpha-\mathrm{Fe}_{2} \mathrm{O}_{3}$ particles, FeZSM-E has three types with a total amount of $75.9 \%$ and more than one type with $32.6 \%$ in FeZSM-F. As most of the framework aluminum exists in the channel [33], $\mathrm{Fe}^{3+}-\mathrm{Al}-\mathrm{Si}$ and $\mathrm{Fe}^{2+}$ are mainly formed in the channel, similar to small $\mathrm{Fe}_{x} \mathrm{O}_{y}$ nanoparticles, whereas large $\alpha-\mathrm{Fe}_{2} \mathrm{O}_{3}$ particles are formed outside the ZSM-5. Thus, we can divide the Fe species into two categories: inside and outside the ZSM-5. In FeZSM-F, most of the iron species $(\sim 67.4 \%)$ are inside the ZSM-5. However, in FeZSM-E, most of the Fe species $(\sim 75.9 \%)$ are outside the ZSM-5. Clearly, freeze drying has a confining effect on the iron species.

Owing to the confinement of the narrow channel (diameter of less than $1 \mathrm{~nm}$ ), the sizes of the iron species inside the ZSM-5 are much smaller than the iron species outside the ZSM-5 (larger than $10 \mathrm{~nm}$ ). Thus, the overall size of the iron species in FeZSM-F is smaller than that in FeZSM-E. This conclusion can be confirmed from another perspective [20]. In the Mössbauer spectra, the particle size of the iron species has a significant impact on the peak type. When the size is below a certain value, the peak type will be the doublet; however, above the value, the peak will turn into the sextet [20]. In FeZSM-F, there are 67.4\% iron species in the doublet, and $32.6 \%$ in the sextet. However, in FeZSM-E, there are only $24.1 \%$ iron species in doublet, and $75.9 \%$ in the sextet. All of the above factors indicate that freeze drying favors the formation of a smaller metal species.

For different valence states, FeZSM-F has more $\mathrm{Fe}^{2+}$ species than FeZSM-E (29.6\% versus 8.9\%), whereas FeZSM-E has more $\mathrm{Fe}^{3+}$ species than FeZSM-F (91.1\% versus 70.4\%), which is also consistent with the trend found in the $\mathrm{H}_{2}$-TPR results. Furthermore, FeZSM-E has more types of iron species than FeZSM-F (7 versus 4), including more $\mathrm{Fe}^{2+}$ (2 versus 1 ) and $\mathrm{Fe}^{3+}$ (5 versus 3 ). Overall, freeze drying contributes more to the formation of $\mathrm{Fe}^{2+}$ and the diversity of the iron species.

Based on the results above, formation mechanisms are displayed in Fig. 4. First, both samples are immersed in a precursor, and the iron species are well dispersed owing to the capillary forces. During the preparation of FeZSM-F, the sample is then frozen, and water is removed through sublimation. In the absence of the capillary force, $\mathrm{Fe}\left(\mathrm{NO}_{3}\right)_{3}$ remains well distrib-

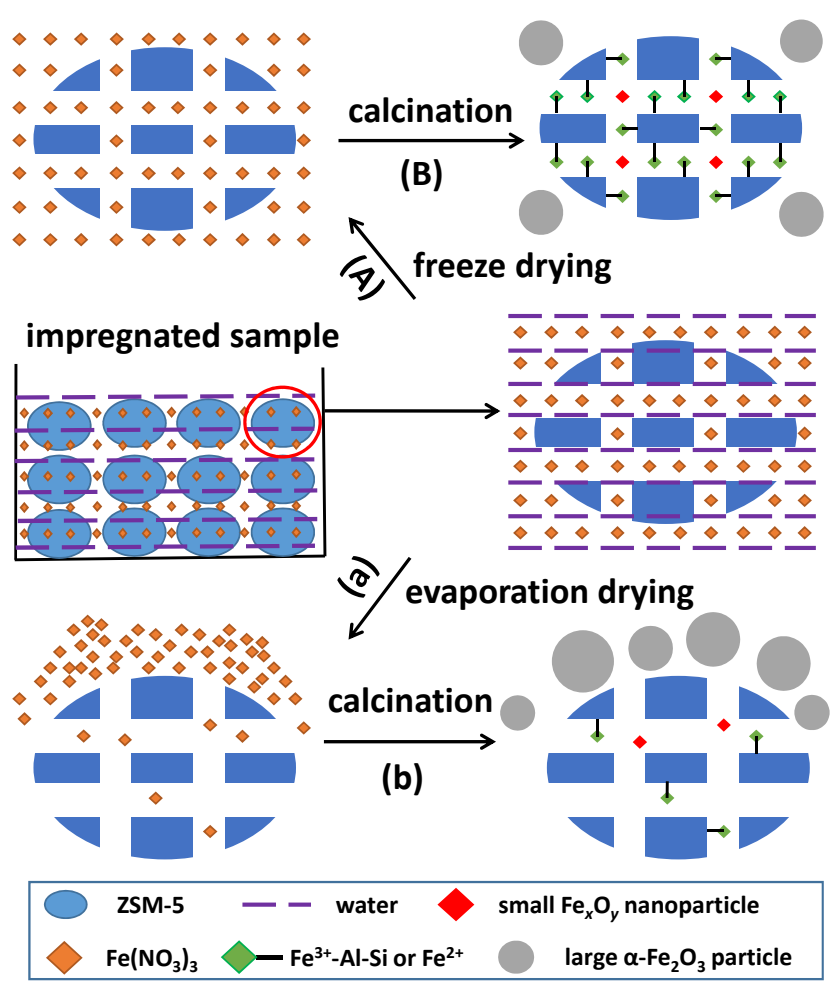

Fig. 4. Schematic overview of preparation steps of FeZSM-5 catalysts.

uted in the ZSM-5 after freeze drying (step (A)). With a large specific surface area and abundant micropores in the ZSM-5, most of the $\mathrm{Fe}\left(\mathrm{NO}_{3}\right)_{3}$ is confined in the channel, and there are more opportunities for $\mathrm{Fe}\left(\mathrm{NO}_{3}\right)_{3}$ to interact with the framework $\mathrm{Al}$ during calcination, resulting in more $\mathrm{Fe}^{3+-} \mathrm{Al}-\mathrm{Si}$ and $\mathrm{Fe}^{2+}$. Because not all $\mathrm{Fe}\left(\mathrm{NO}_{3}\right)_{3}$ is able to contact the limited framework $\mathrm{Al}$, the remaining $\mathrm{Fe}\left(\mathrm{NO}_{3}\right)_{3}$ in the channel will form small $\mathrm{Fe}_{x} \mathrm{O}_{y}$ nanoparticles. Owing to the confinement of the channel, the sizes of the iron species are rather small. Only a few $\mathrm{Fe}\left(\mathrm{NO}_{3}\right)_{3}$ outside the ZSM-5 will form large $\alpha-\mathrm{Fe}_{2} \mathrm{O}_{3}$ particles. Because the concentration of $\mathrm{Fe}\left(\mathrm{NO}_{3}\right)_{3}$ is uniform, large $\alpha-\mathrm{Fe}_{2} \mathrm{O}_{3}$ particles of only one size are formed (step (B)). However, in the preparation of FeZSM-E, during evaporation drying, most of the $\mathrm{Fe}\left(\mathrm{NO}_{3}\right)_{3}$ is transported along the channel by the capillary force to the external layer, and accumulates on the surface of the ZSM-5 (step a). Without the restriction of narrow channels, many large $\alpha-\mathrm{Fe}_{2} \mathrm{O}_{3}$ particles $(>10 \mathrm{~nm})$ are formed after calcination. In addition, only a few $\mathrm{Fe}\left(\mathrm{NO}_{3}\right)_{3}$ particles are confined in the channel, producing fewer $\mathrm{Fe}^{3+}-\mathrm{Al}-\mathrm{Si}, \mathrm{Fe}^{2+}$, and small $\mathrm{Fe}_{x} \mathrm{O}_{y}$ nanoparticles. Because the concentration differs in various parts, two $\mathrm{Fe}^{2+}$ types and three different sizes of large $\alpha-\mathrm{Fe}_{2} \mathrm{O}_{3}$ particles are formed (step (b)).

Herein, we suppose that the two $\mathrm{Fe}^{2+}$ species contain different iron nucleus, which depends on the distance between the iron atoms. For FeZSM-E, the distribution of iron is non-uniform inside the ZSM-5. In the low iron concentration part, the distance between two iron atoms is relatively large, and it may be easier to form Doublet(B) (mononuclear $\mathrm{Fe}^{2+}$ ); however, in the high concentration part, the distance is relatively small, and it may be easier to form a multinuclear species. Doublet(A) $\left(\mathrm{Fe}^{2+}\right.$ in $\mathrm{O}_{\mathrm{h}}$ coordination) is speculated to con- 
Table 2

TOF of $\mathrm{N}_{2} \mathrm{O}$ decomposition for FeZSM- 5 catalysts.

\begin{tabular}{lcc}
\hline Catalyst & \multicolumn{2}{c}{ TOF $_{\mathrm{N} 20}\left(\mathrm{~s}^{-1}\right)$} \\
\cline { 2 - 3 } & $420^{\circ} \mathrm{C}$ & $440^{\circ} \mathrm{C}$ \\
\hline FeZSM-E & 1900 & 3100 \\
FeZSM-F & 4200 & 9500 \\
\hline
\end{tabular}

tain two or more iron atoms. For FeZSM-F, the iron is uniformly distributed, and the concentration is insufficiently low to create the mononuclear species, and thus only Doublet(A) is formed.

To verify the difference in composition, the catalysts are tested through $\mathrm{N}_{2} \mathrm{O}$ decomposition reaction. The active centers in the $\mathrm{N}_{2} \mathrm{O}$ decomposition are a series of Fe species. After high-temperature treatment in inert gas, some $\mathrm{Fe}^{3+}$ will be reduced to $\mathrm{Fe}^{2+}$, which are the active centers [29,31,33-36]. Although the structure of the active $\mathrm{Fe}^{2+}$ remains under debate, there is a consensus that $\mathrm{Fe}^{2+}$ should be connected with $\mathrm{Al}$. Some authors have ascribed the active centers to bare $\mathrm{Fe}^{2+}$ or a $\mathrm{Fe}^{2+-} \mathrm{O}-\mathrm{Fe}^{2+}$ complex stabilized by $\mathrm{Al}^{3+}$ pairs, whereas others have considered square planer mononuclear $\mathrm{Fe}(\mathrm{II})$ in the $\beta$-6MRs, which contains two Al T-sites, as the active center $[32,37]$. Small $\mathrm{Fe}_{x} \mathrm{O}_{y}$ nanoparticles are also responsible for such activity [30]. However, large $\mathrm{Fe}_{2} \mathrm{O}_{3}$ particles are inactive or have low activity, which is also shown through our experiment (Table S2). Thus, Doublet(A), Doublet(B), and Doublet(II) are ascribed to active species. Because there are more active species over FeZSM-F than FeZSM-E (57.0\% versus 21.1\%), FeZSM-F should exhibit a higher activity. $\mathrm{N}_{2} \mathrm{O}$ decomposition activities at 420 and $440{ }^{\circ} \mathrm{C}$ are illustrated in Table 2 . With the same Fe content in both catalysts, different TOF $_{\mathrm{N} 20}$ (turnover frequencies, per Fe atoms per second) indicate the distinction of the Fe species. As expected, FeZSM-F has a higher TOF 20 . At $420{ }^{\circ} \mathrm{C}$, TOF ${ }_{\mathrm{N} 20}$ for FeZSM-F is 2.2-times that for FeZSM-E, whereas at $440{ }^{\circ} \mathrm{C}$, both $\mathrm{TOF}_{\mathrm{N} 20}$ increase significantly, and TOF $_{\mathrm{N} 20}$ for FeZSM-F is 3.1-times that for FeZSM-E. Fig. 5 shows

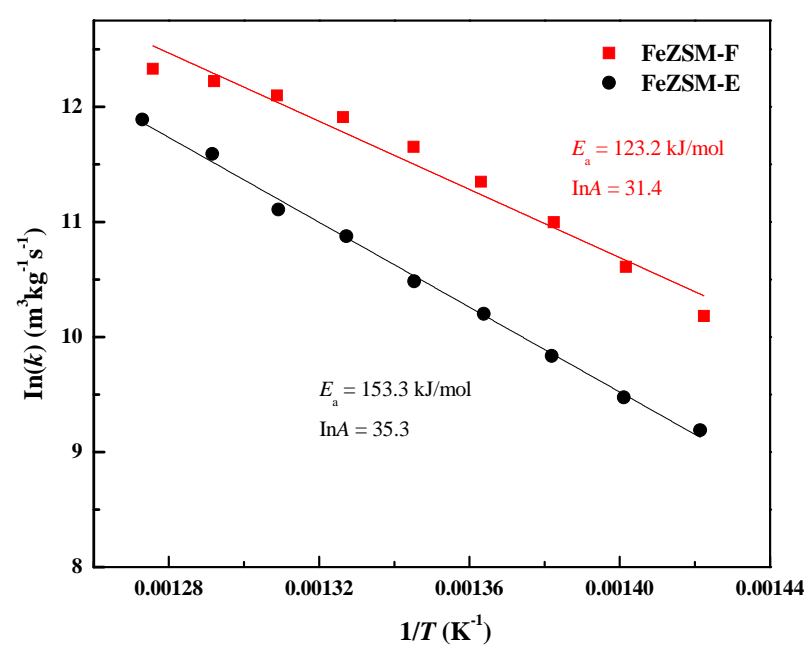

Fig. 5. Arrhenius plots of In $k$ versus $1 / T$ for $\mathrm{N}_{2} \mathrm{O}$ decomposition over FeZSM- 5 catalysts.
Arrhenius plots of the $\mathrm{N}_{2} \mathrm{O}$ decomposition $\left(430-510{ }^{\circ} \mathrm{C}\right)$. The value of $E_{\mathrm{a}}$ (activation energy) is lower in FeZSM-F (123.2 $\mathrm{kJ} / \mathrm{mol}$ ) than in FeZSM-E (153.3 kJ/mol).

\section{Conclusions}

To summarize, freeze-drying impregnation is applied in the preparation of $57 \mathrm{FeZSM}-5$. Compared with the traditional evaporation-drying catalyst, more iron species are confined inside ZSM-5 in a freeze-drying catalyst, creating enhanced metal-support interactions, smaller sized species, and less diversity. The difference in the composition is also proved based on the superior performance of the freeze-drying catalyst during $\mathrm{N}_{2} \mathrm{O}$ decomposition. For preparation of the supported metal catalysts, in most cases, the metal-support interaction and the size of the metal species are vital for the reaction, and our study provides a general way to tune the metal-support interactions and the size of the metal species in impregnation method, which can be extended to other metals and supports.

\section{References}

[1] H. Tang, Y. Su, B. Zhang, A. F. Lee, M. A. Isaacs, K. Wilson, L. Li, Y. Ren, J. Huang, M. Haruta, B. Qiao, X. Liu, C. Jin, D. Su, J. Wang, T. Zhang, Sci. Adv., 2017, 3, e1700231/1-e1700231/8.

[2] C. Linsmeier, E. Taglauer, Appl. Catal. A, 2011, 391, 175-186.

[3] G. M. Mullen, E. J. Evans, B. C. Siegert, N. R. Miller, B. K. Rosselet, L. Sabzevari, A. Brush, Z. Duan, C. B. Mullins, React. Chem. Eng., 2018, 3, 75-85.

[4] B. Jin, Y. Wei, Z. Zhao, J. Liu, Y. Li, R. Li, A. Duan, G. Jiang, Chin. J. Catal., 2017, 38, 1629-1641.

[5] Z. Li, X. Yang, Y. Yang, Y. Tan, Y. He, M. Liu, X. Liu, Q. Yuan, Chem. Eur. J., 2018, 24, 409-415.

[6] X. Qian, Y. Kuwahara, K. Mori, H. Yamashita, Chem. Eur. J., 2014, 20, 15746-15752.

[7] H. Tang, F. Liu, J. Wei, B. Qiao, K. Zhao, Y. Su, C. Jin, L. Li, J. Liu, J. Wang, T. Zhang, Angew. Chem. Int. Ed., 2016, 55, 10606-10611.

[8] J. C. Matsubu, S. Zhang, L. DeRita, N. S. Marinkovic, J. G. Chen, G. W. Graham, X. Pan, P. Christopher, Nat. Chem., 2017, 9, 120-127.

[9] K. Wilson, A. F. Lee, Heterogeneous Catalysts for Clean Technology: Spectroscopy, Design, and Monitoring, VCH, Weinheim, 2013, 374.

[10] G. Rothenberg, Catalysis: Concepts and Green Applications, VCH, Weinheim, 2008, 139.

[11] J. Regalbuto, Catalyst Preparation: Science and Engineering, CRC Press, Boca Raton, 2006, 375-386.

[12] T. Vergunst, F. Kapteijn, J. A. Moulijn, Appl. Catal. A, 2001, 213, 179-187.

[13] G. Bond, R. B. Moyes, D. A. Whan, Catal. Today, 1993, 17, 427-437.

[14] W. Abdelwahed, G. Degobert, S. Stainmesse, H. Fessi, Adv. Drug Deliv. Rev., 2006, 58, 1688-1713.

[15] T. M. Eggenhuisen, P. Munnik, H. Talsma, P. E. de Jongh, K. P. de Jong, J. Catal., 2013, 297, 306-313.

[16] X. Xi, Z. Nie, Y. Jiang, X. Xu, T. Zuo, Powder Technol., 2009, 191, 107-110.

[17] O. A. Anunziata, M. G. Costa, A. R. Beltramone, Appl. Catal. A, 2006, 307, 263-269.

[18] S. Kachi, K. Momiyama, S. Shimzu, J. Phys. Soc. Jpn., 1963, 18, 106-116. 


\title{
Graphical Abstract
}

Chin. J. Catal., 2019, 40: 1109-1115 doi: 10.1016/S1872-2067(18)63198-5

Preparation of highly dispersed iron species over ZSM-5 with enhanced metal-support interaction through freeze-drying impregnation

Lisong Fan, Dang-guo Cheng *, Fengqiu Chen, Xiaoli Zhan Zhejiang University

For preparation of supported metal catalysts through impregnation, freeze drying provides a general way to tune the metal-support interactions and the metal size.

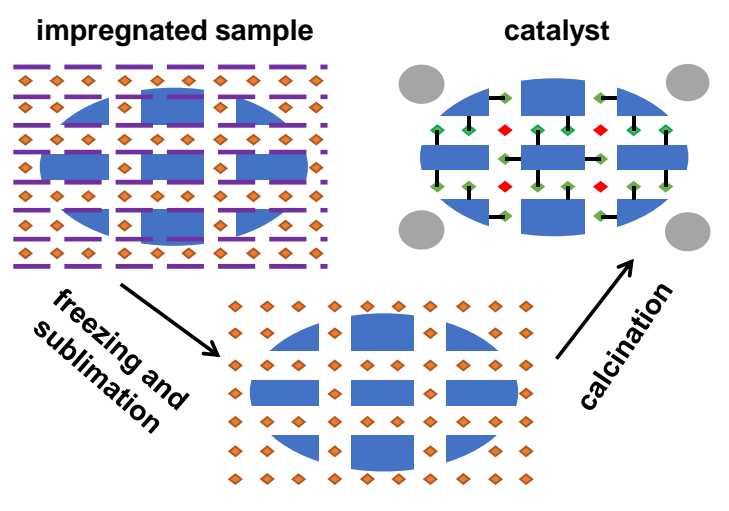

[19] P. Sazama, B. Wichterlová, E. Tábor, P. Št’astný, N. K. Sathu, Z. Sobalík, A. Vondrová, J. Catal., 2014, 312, 123-138.

[20] L. Luo, C. Dai, A. Zhang, J. Wang, M. Liu, C. Song, X. Guo, RSC Adv., 2015, 5, 29509-29512.

[21] S. Song, G. Wu, W. Dai, N. Guan, L. Li, Catal. Sci. Technol., 2016, 6, 8325-8335.

[22] X. Li, K. Zhu, J. Pang, M. Tian, J. Liu, A. I. Rykov, M. Zheng, X. Wang, X. Zhu, Y. Huang, B. Liu, J. Wang, W. Yang, T. Zhang, Appl. Catal. B, 2018, 224, 518-532.

[23] V. B. Aubé, O. Marie, J. Saussey, A. Plesniar, M. Daturi, N. Nguyen, C. Hamon, M. Mihaylov, E. Ivanova, K. Hadjiivanov, J. Phys. Chem. C, 2009, 113, 8387-8393.

[24] A. R. Overweg, M. W. J. Crajé, A. M. van der Kraan, I. W. C. E. Arends, A. Ribera, R. A. Sheldon, J. Catal., 2004, 223, 262-270.

[25] E. Tabor, K. Závěta, N. K. Sathu, A. Vondrova, P. Sazama, Z. Sobalik, Catal. Today, 2011, 175, 238-244.

[26] P. Sazama, N. K. Sathu, E. Tabor, B. Wichterlová, Š. Sklenák, Z. Sobalík, J. Catal., 2013, 299, 188-203.

[27] K. Lázár, O. Pozdnyakova, A. Wootsch, P. Fejes, Hyperfine Interact., 2006, 167, 779-784.
[28] G. Moretti, G. Fierro, G. Ferraris, G. B. Andreozzi, V. J. Naticchioni, J. Catal., 2014, 318, 1-13.

[29] G. Fierro, G. Moretti, G. Ferraris, G. B. Andreozzi, Appl. Catal. B, 2011, 102, 215-223.

[30] P. Xie, Y. Luo, Z. Ma, C. Huang, C. Miao, Y. Yue, W. Hua, Z. Gao, J. Catal., 2015, 330, 311-322.

[31] B. E. R. Snyder, P. Vanelderen, M. L. Bols, S. D. Hallaert, L. H. Böttger, L. Ungur, K. Pierloot, R. A. Schoonheydt, B. F. Sels, E. I. Solomon, Nature, 2016, 536, 317-321.

[32] G. Sádovská, E. Tabor, P. Sazama, M. Lhotka, M. Bernauer, Z. Sobalík, Catal. Commun., 2017, 89, 133-137.

[33] Q. Zhao, W. H. Chen, S. J. Huang, Y. C. Wu, H. K. Lee, S. B. Liu, J. Phys. Chem. B, 2002, 106, 4462-4469.

[34] G. D. Pirngruber, P. K. Roy, R. Prins, J. Catal., 2007, 246, 147-157.

[35] K. Sun, H. Xia, E. Hensen, R. van Santen, C. Li, J. Catal., 2006, 238, 186-195.

[36] K. A. Dubkov, N. S. Ovanesyan, A. A. Shteinman, E. V. Starokon, G. I. Panov, J. Catal., 2002, 207, 341-352.

[37] J. H. Park, J. H. Choung, I. S. Nam, S. W. Ham, Appl. Catal. B, 2008, $78,342-345$

\section{冷冻干燥浸渍法制备具有高分散铁物种和强金属-载体相互作用的 FeZSM-5催化剂}

\author{
范立䇯, 程党国 ${ }^{*}$, 陈丰秋, 詹晓力 \\ 浙江大学化学工程与生物学院, 浙江省化工高效制造技术重点实验室, 浙江杭州310027
}

\begin{abstract}
摘要: 负载型催化剂在现代化工中发挥着重要作用. 其中, 金属与载体的相互作用是负载型催化剂的重要特性. 浸渍法是 制备这类催化剂的一种简便方法. 然而, 传统浸渍法在浸渍达到平衡后采用蒸发干燥时, 大量金属前驱体在毛细管力的作 用下沿着孔道迁移并堆积在载体表面, 焙烧后形成大块的金属团簇, 这使得到的催化剂中金属与载体相互作用较弱. 有研 究者在浸渍溶液中添加高粘度物质来降低毛细管力的影响, 或者采用微波干燥来减少团簇的产生, 但总体上关于浸渍法中 增强金属与载体相互作用的通用性方法研究很少. 为此, 本文采用冷冻干燥对传统的浸渍法进行改进. 冷冻干燥是一种将 冰冻样品置于真空条件下使溶剂升华的干燥方式, 在化学上主要用于制备纳米金属粉末, 很少用来制备金属负载型催化 剂. 本文以 ${ }^{57} \mathrm{FeZSM}-5$ 为例, 采用传统蒸发干燥和改进的冷冻干燥方法制备了两种催化剂, 采用超导量子干涉仪(SQUID), $\mathrm{H}_{2}$-TPR和穆斯堡尔谱等表征手段研究了两者在铁物种组成和 $\mathrm{N}_{2} \mathrm{O}$ 分解活性上的区别, 并提出了形成机理.
\end{abstract}

SQUID测试表明, 两种催化剂均具有铁磁性和顺磁性特性, 这意味着催化剂中可能存在 $\alpha-\mathrm{Fe}_{2} \mathrm{O}_{3}$, 以及与骨架相连的二 
价或三价铁物种. $\mathrm{H}_{2}$-TPR结果显示, 冻干催化剂中含有更少的铁物种数和更多的 $\mathrm{Fe}^{2+}$ 含量. 进一步的穆斯堡尔谱表征不仅 印证了上述结果, 而且给出了铁物种的定量结果. 相比于传统的蒸干催化剂, 冻干催化剂拥有更多与分子篮骨架铝相连的 铁物种, 说明冷冻干燥可以增强金属与载体的相互作用. 在冻干催化剂中, 更多的铁物种存在于孔道内, 说明冷冻干燥对 铁物种有着良好的限域作用. 此外, 冻干催化剂含有更多纳米级金属氧化物, 大块团簇较少, 金属物种的平均尺寸小于蕉 干催化剂. 冻干催化剂在 $\mathrm{N}_{2} \mathrm{O}$ 分解中更高的活性也证明了铁物种结构的变化.

基于上述结果, 本文提出了不同干燥方式下铁物种的形成机理. 在蒸干催化剂中, 由于蒸发过程中毛细管力的存在, 原本在载体中均匀分散的铁前驱体被转移到载体表面, 形成大量的大块铁团簇. 而对于冻干催化剂, 溶剂是通过升华的方 式去除, 铁前驱体不会受干燥的影响而保持均匀分布的状态. 由于ZSM-5分子篮拥有丰富的孔隙, 大量铁被限制在狭窄的 孔道中, 所形成的铁物种尺寸更小, 同时铁有更多机会与骨架铝发生相互作用, 从而达到增强金属与载体相互作用的目的. 该方法属于浸渍法的通用性改进, 可以在制备其他负载型催化剂时调控金属与载体的相互作用以及金属尺寸大小.

关键词: 铁; ZSM-5分子篮; 冷冻干燥; 浸渍法; 金属与载体相互作用; 金属粒径

收稿日期: 2018-10-04. 接受日期: 2018-11-09. 出版日期: 2019-07-05.

*通讯联系人. 电话: (0571)87953382; 传真: (0571)87951227; 电子信箱: dgcheng@zju.edu.cn

基金来源：国家重点研发计划(2016YFA0202900); 国家自然科学基金(21622606); 浙江省自然科学基金(LR18B060001); 中央高 校基本科研业务费专项资金.

本文的电子版全文由Elsevier出版社在ScienceDirect上出版(http://www.sciencedirect.com/science/journal/18722067). 